\title{
血行動態介入による脳動脈瘤の血行力学的治療
} -3 症例の検討と文献的考察—

\author{
脊山 英徳, 野口 明男, 栗田 浩樹 ${ }^{2}$ \\ 佐藤 栄志 ${ }^{1}$, 小西 善史 ${ }^{1}$, 塩川 芳昭 ${ }^{1}$
}

\section{Flow Alteration Concept of Intracranial Aneurysms Not Amenable to Direct Aneurysmal Obliteration. Report of Three Cases and Literature Review}

\author{
Hidenori Seyama, M.D., ${ }^{1}$ Akio Noguchi, M.D., ${ }^{1}$ Hiroki Kurita, M.D., ${ }^{2}$ Eishi Sato, M.D., ${ }^{1}$ \\ Yoshifumi Konishi, M.D., ${ }^{1}$ and Yoshiaki SHIOKawA, M.D. ${ }^{1}$ \\ ${ }^{1}$ Department of Neurosurgery, Kyorin University, Mitaka, Tokyo, and ${ }^{2}$ Department of \\ Cerebrovascular Surgery, Saitama Medical University International Medical Center, Hidaka, \\ Saitama, Japan
}

Summary: We report three cases treated with the same concept for intracranial aneurysms not amenable to direct aneurysmal obliteration. Our treatment strategy is to reduce the hemodynamic burden of aneurysms and avoid ischemic complications of perforating arteries. It consists of isolation of several branches from the parent artery of the aneurysm with bypasses and endovascular techniques. Three treated cases comprised two partially thrombosed unruptured aneurysms and one ruptured dissecting aneurysm. Although the three cases involved different disease entities, they were treated under the same treatment concept, and the patients obtained good results. In the two partially thrombosed aneurysms, almost complete or virtually complete thrombosis had been achieved, and significant shrinkage of the aneurysm was observed. Our strategy prevented aneurysmal rupture in all cases, and is considered effective in promoting thrombosis of the aneurysm. All the demonstrated cases also showed shrinkage of the aneurysm. Further study on this treatment concept is necessary to confirm its clinical efficacy and safety.

\section{Key words:}

- intracranial aneurysm

- treatment strategy

- bypass surgery

Surg Cereb Stroke (Jpn) 40: 425-430, 2012
はじめに

脳動脈瘤の第一の治療目標は破裂予防であり, 治療適応 を有する場合は瘤内血流の遮断を目的に頝部クリッピング や瘤内コイル塞栓術などが施行される. しかし, 大型動脈 瘤や解離性動脈瘤, 紡錘状動脈瘤などでは瘤内血流の遮断
が困難な場合がある。これら治療困難な脳動脈瘤に対して も,「動脈瘤に対する血流負荷を軽減する」「治療に伴う合 併症, 特に穿通枝障害を生じさせない」という治療コンセ プトは疾患の自然史や患者予後の改善に貢献しうると考え る. 今回, この治療コンセプトに基づいた脳動脈瘤治療 3 症例について報告し, 文献的考察を加えた.

${ }^{1}$ 杏林大学医学部 脳神経外科, ${ }^{2}$ 埼玉医科大学国際医療センター 脳卒中外科(受稿日 2012.3.11)(脱稿日 2012.9.20)〔連絡先： テ 1818611 東京都三鷹市新川 6-20-2 杏林大学 脳神経外科 脊山英徳] [Address correspondence: Hidenori SEYAMA, M.D., Department of Neurosurgery, Kyorin University, 6-20-2 Shinkawa, Mitaka, Tokyo 181-8611, Japan] 


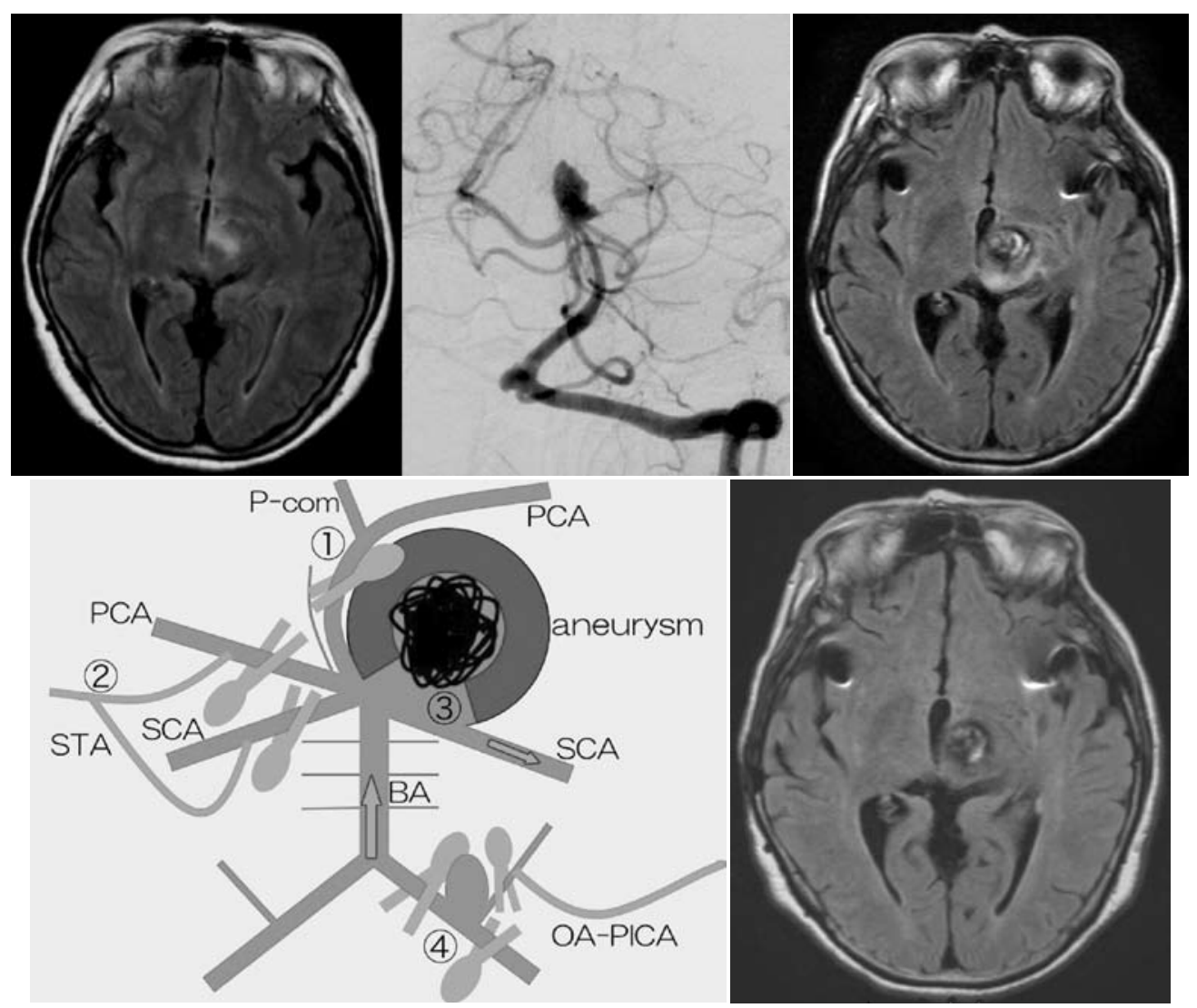

Fig. 1 A: left: Magnetic resonance image demonstrating a partially thrombosed unruptured aneurysm compressing the midbrain with perifocal edema. right: A digital subtraction angiogram revealing the blood-flow lumen of the aneurysm.

B: Magnetic resonance image obtained on postoperative 10 months later shown remarkable deterioration of the perifocal edema.

C: Schematic drawing illustrating the staged flow reduction procedure. (1)(2): The A $\mid$ B partially thrombosed aneurysm became isolated from branches with bypasses. (3): Selective coiling of the remaining lumen of the aneurysm was performed. (4): Left vertebral artery was occluded with OA-PICA bypass.

D: Magnetic resonance images obtained after maximum flow reduction procedure showing relief of the perifocal edema.

\section{対象}

2006 年 5 月～ 2010 年 11 月に杏林大学病院脳神経外科 に入院し，治療を施行した脳動脈瘤 3 症例 (平均年齢 56.3 歳, 全例女性)。全例症候性で, そのうち 1 例はくも膜下 出血発症であった. 治療の前には当該動脈瘤が基本的な治 療手技で閉塞が困難であること, および血行動態の変更に よる治療により予見しがたい状況も起こりうること, など を十分に説明し，同意を得たうえで治療を実施した。

〈症例 1〉58 歳, 女性. 頭痛の精查にて未破裂部分血栓 化大型左脳底動脈一上小脳動脈分岐部 (basilar artery-superior cerebellar artery: BA-SCA)動脈溜を認めた。他に未 破裂左中大脳動脈分岐部 (middle cerebral artery: MCA) 動脈瘤, 未破裂右 MCA 動脈瘤と未破裂左椎骨動脈一後下
小脳動脈 (vertebral artery-posterior inferior cerebellar artery：VA-PICA) 分岐部動脈痕を合併していた。徐々に 瘤内血栓の増大により (Fig. 1A), 左動眼神経麻痺が進行 したため治療を施行した．親血管との関係や瘤内血栓の大 きさから, 根治的な䅡部クリッピングは困難と考え, water hammer effect の軽減を目的として両側後大脳動 脈 (posterior cerebellar artery: PCA) と右 SCA BA か ら遮断し左 SCA のみの血流を温存する治療計画を立てた。 第 1 回目の手術は, 左 BA-SCA 分岐部近傍の観察も併せ て行うため, 左前頭側頭開頭とした。動脈瘤はBA-SCA 分岐部であったが, 動脈瘤䅡部が BA 全体を含む形で拡大 しており，頝部クリッピングは困難であることを直視下で 確認した. 左 PCA の P1 を遮断して左 PCA 遠位部血流は 左 p-com から灌流するようにした。第 2 回目の手術は, 

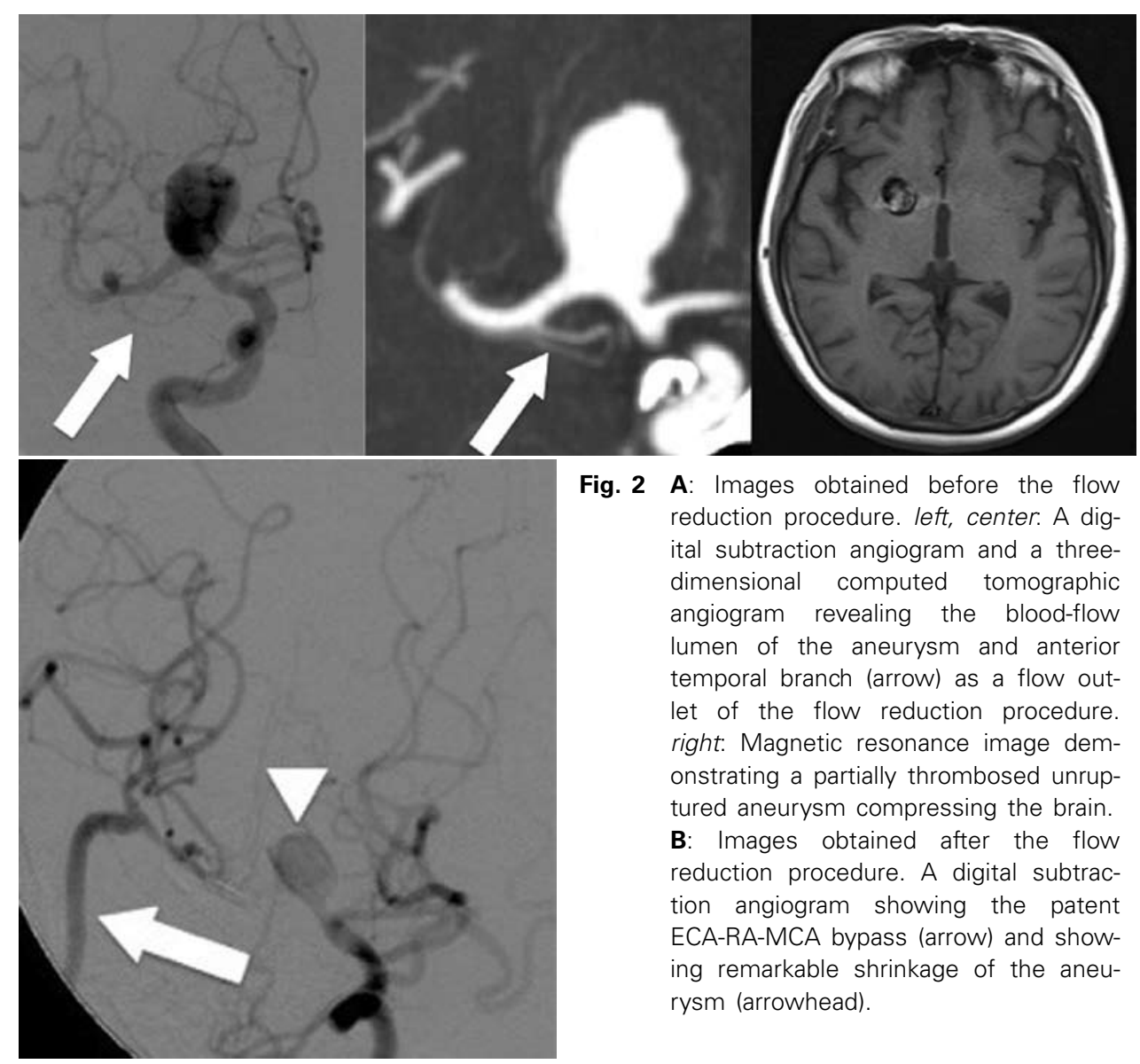

Fig. 2 A: Images obtained before the flow reduction procedure. left, center. A digital subtraction angiogram and a threedimensional computed tomographic angiogram revealing the blood-flow lumen of the aneurysm and anterior temporal branch (arrow) as a flow outlet of the flow reduction procedure. right: Magnetic resonance image demonstrating a partially thrombosed unruptured aneurysm compressing the brain. B: Images obtained after the flow reduction procedure. A digital subtraction angiogram showing the patent ECA-RA-MCA bypass (arrow) and showing remarkable shrinkage of the aneurysm (arrowhead).

右前頭側頭開頭にて右浅側頭動脈 (superficial temporal artery: STA)-PCA 吻合術, 右 STA-SCA 吻合術を行い, 右 PCA (P1) と右 SCA 起始部にクリップを掛けて BA か ら遮断した。第 2 回手術後に左 BA-SCA 動脈瘤は縮小を 認めた。この還流血流量の軽減のみで動脈瘤の安定的縮小 が得られると想定していたが, 約 10 カ月後に左 BA-SCA 動脈瘤が再増大し (Fig. 1B), 不全右麻疩が出現した。さ らなる血行動態介入が必要であり, 第 3 回目手術は脳血管 内治療にて左 BA-SCA 動脈瘤内コイル塞栓術を施行した. 引き続き 2 日後に第 4 回目の手術として, flow reduction を目的とした左後頭動脈 (occipital artery: OA)-PICA 吻 合十左 VA-PICA 動脈瘤 trapping 術を行った(Fig. 1C). この最大限の血行動態介入により, 左 BA-SCA 動脈瘤へ の順行性の血流は残存しているものの, 動脈瘤は再度縮小

\section{した(Fig. 1D).}

〈症例 2〉70 歳, 女性. 頭痛の精査で未破裂部分血栓化 大型右 $\mathrm{MCA}$ 動脈瘤を認めた. 半年後に増大を認め (Fig. 2A），また右側に限局した強い頭痛を自覚したため治療を 施行した. 動脈瘤の形状, 血栓の厚みや穿通枝との関係か ら，穿通枝を温存した形での頚部クリッピングは困難と考 えた，右 MCAの anterior temporal branch が動脈瘤の
遠位部 M1 より分岐していたため(Fig. 2A 矢印)，この分 枝のみを flow outlet とすることで穿通枝の血流を温存す ると同時に, 動脈瘤開口部を通過する灌流血流量の軽減を することとした．右 MCA の灌流領域に対しては右 ECA橈骨動脈グラフト(radial artery graft: RAG)-右 MCA M2 吻合術を置き, anterior temporal branch と M2 分岐 部の間で M1 をクリップで遮断した． 1 本の穿通枝が M2 分岐部近傍に存在し, anterior temporal branchへの順行 性の flow 内に入らなかった，その結果，この穿通枝領域 に症候性脳梗塞が出現し, 軽度左不全麻瘦を生じたが, 動 脈瘤は顕著に縮小した(Fig. 2B)，頭痛は消失し，左不全 片麻瘏は軽快し, modified Rankin Scale 1 で独歩自宅退 院した.

〈症例 3〉41 歳, 女性. 多発腎囊胞, 多発肝囊胞, 潰瘍 性大腸炎にて加療中にくも膜下出血を発症した. 出血源精 查にて破裂 BA 解離性動脈瘤を認め, 保存的加療を行って いたが, 第 14 病日に再破裂と動脈瘤様隆起の増大を呈し た（Fig. 3A）。まず急性期の再出血予防目的に動脈瘤様隆 起に対する瘤内コイル塞栓術十右 VA 閉塞(PICA 近位部 閉塞)を行った(Fig. 3B). 動脈瘤様隆起に対してコイル塞 栓を行ったが，母血管に解離部位が残存しており，順行性 

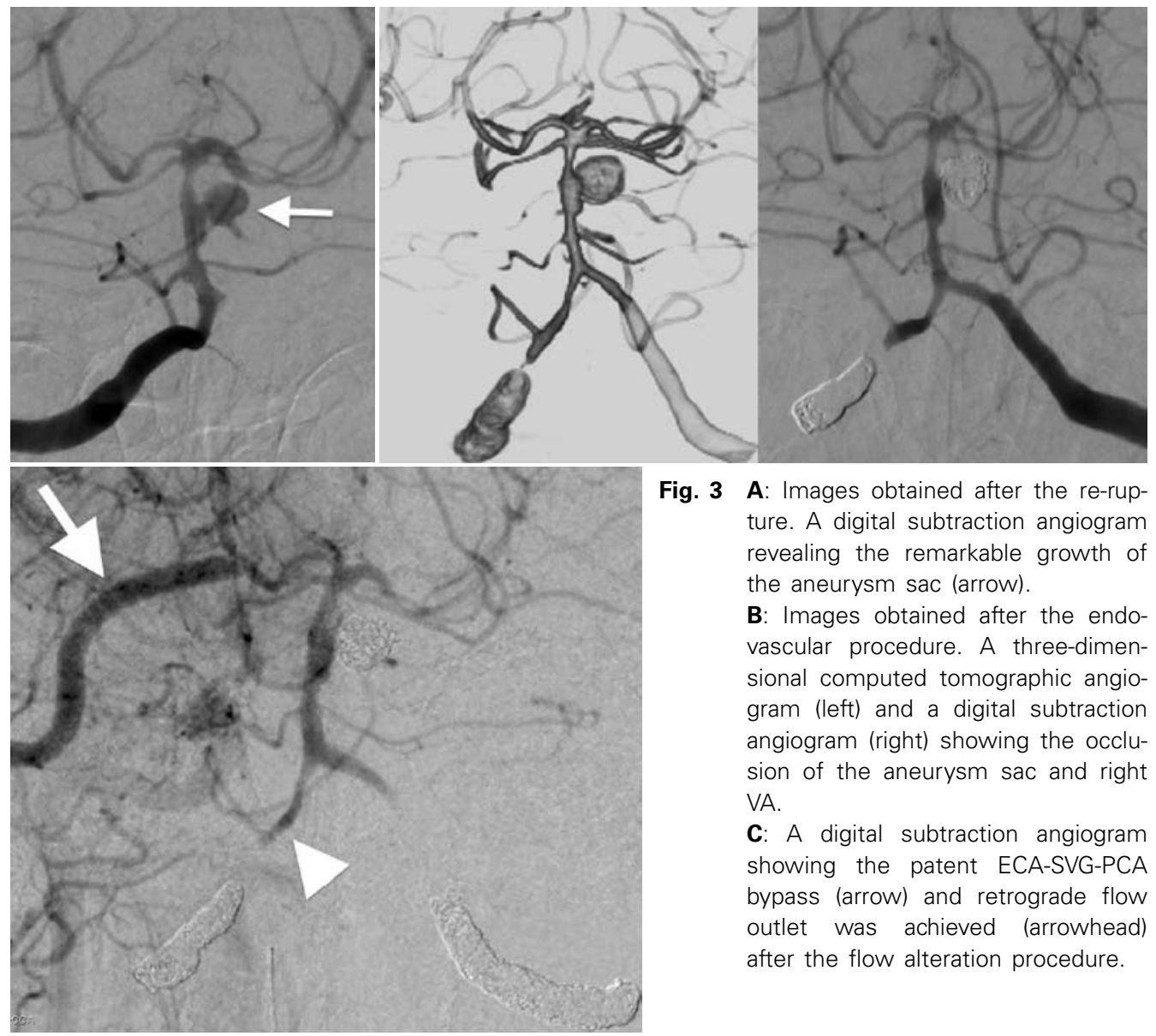

Fig. 3 A: Images obtained after the re-rupture. A digital subtraction angiogram revealing the remarkable growth of the aneurysm sac (arrow).

B: Images obtained after the endovascular procedure. A three-dimensional computed tomographic angiogram (left) and a digital subtraction angiogram (right) showing the occlusion of the aneurysm sac and right VA.

C: A digital subtraction angiogram showing the patent ECA-SVG-PCA bypass (arrow) and retrograde flow outlet was achieved (arrowhead) after the flow alteration procedure.

の血流負荷の軽減を目的に, 両側 PICA を flow outlet と する血流変更を行うこととした. P-com が両側とも adult type であったことから, high flow な血行再建が必要と判 断した. 手術に伴う脳損傷の危険性も考慮して, 右側での 血行再建術を行い, 左 VA 近位部の閉塞が可能かどうか バルーン閉塞試験(balloon occlusion test: BOT)で判断す ることとした。まず第 32 病日に右外頝動脈 (external carotid artery: ECA) -大伏在静脈 (saphenous vein graft: SVG) - 右 PCA 吻合術を施行した。第 33 病日に左 VA の 治療的閉塞を目的として PICA 近位部でBOTを施行し た. 30 分間の閉塞中, 体性感覚誘発電位 (somatosensory evoked potential: SEP)/聴性脳幹反応 (auditory brainstem response: ABR)のモニターと神経症状に変化なく, 遮断時の stump pressure が体血圧の $50 \%$ を維持できて いた. 左 VAの PICA proximalでの閉塞に脳虚血耐性が あると判定した。 また, SVGバイパスからの撮影で, 両 側 PCA ・ SCA と, 両側 PICA への逆行性の血流を確認さ れ, 追加の血行再建は不要と判断した. 左VAのPICA 近位部をコイルで閉塞した(Fig. 3C). 軽微な小脳梗塞を 認めたが, 神経症状は出現せず, 独歩にて自宅退院した.
その後, 1 年 6 力月間の定期的画像診断フォローを施行し ているが, 解離性動脈瘤の再発やくも膜下出血の再発は認 めていない.

\section{結果}

3 例とも, 血流負荷を軽減させる治療後に脳動脈瘤の破 裂はなく, 部分血栓化動脈瘤は 2 例とも縮小を認めた。症 候性の穿通枝脳梗塞が 1 例 (症例 2)に認められたが, 症状 は軽快し 3 例とも独歩にて自宅退院が可能であった.

\section{考察}

瘤内血流の遮断が困難な脳動脈瘤の自然歴が不良である ことはよく知られている ${ }^{812)}$. しかしわれわれは, 根治的 な瘤内血流遮断が困難な脳動脈瘤でも, 症候を有する症例 や破裂症例に対しては積極的な治療の適応があると考えて いる，その治療コンセプトは，(1)動脈瘤に対する血流負荷 を軽減させることで破裂させない・増大させない, (2)治療 に伴う穿通枝脳梗塞を生じないというもので，血管吻合技 術を適切に用い, 脳血管内治療の進歩に則した治療戦略を 立てている，血管吻合技術に加え，脳血管内治療を複合的 
に組み合わせた治療が全体の侵襲低減に貢献すると考えて いる.

Steinberg らは 201 例の瘤内血流の遮断が困難な VA/ $\mathrm{BA}$ 動脈瘤についての治療成績を報告している 近位部閉塞により治療を行っているが，70\% 弱が良好な 予後が得られた一方， $24 \%$ が死亡したと報告している. P-com の太さが遮断遠位部の脳虚血耐性の予測因子である ことを示した，氏家らは後頭蓋窩血栓性巨大脳動脈瘤の外 科治療について 14 例のシリーズを報告している ${ }^{13)}$. VA に局在する病変の治療は良好であったが，BA 本幹を巻き 込む病変の予後は厳しいものであった。 このシリーズで予 後が不良であったのは， BA 本幹そのものが拡張する，い わゆる BA dolichoectasiaであった，BA 本幹に病巣を有 し，穿通枝が拡張部から分岐する BA dolichoectasia に対 する有効な治療法はいまだ一定の見解を得ないが，後述す る高橋らの遠位分枝への血管吻合と順行性の flow out 併用した血流の低灌流化は, 治療困難な動脈瘤への対応を 考慮するうえで重要な指摘である ${ }^{11)}$ 。一方で Kellner らは 治療困難な $\mathrm{BA}$ 先端部の大型動脈瘤に関して, 後方循環へ の側副血行路が豊富に認められる場合は, 直視下で BA 近 位部をクリップするのが有効であると報告している6). 彼 らは 15 例報告で 1 例の死亡を認めるほかはすべて長期的 な modified Rankin Scaleで0, 1,2を達成したとしている. 死亡した 1 例は, 術 4 時間後に生じた遠位部 BA の血栓化 により中脳梗塞に到ったものであった。コイルによる BA 近位部閉塞よりも, 一点で閉塞する外科的 $\mathrm{BA}$ 近位部閉塞 の方が, 安全で有効であると結論づけている.このように， 瘤内血流の遮断が困難な脳動脈瘤の近位部を閉塞する治療 は，良好な転帰を得られる症例も多いが，予後不良となる 原因としては穿通枝障害が示唆されている. Takahashi ら は部分血栓化 BA top 動脈瘤に対して近位部 BA 閉塞施行 したが効果不十分であった症例に，深部血管吻合を併用し た血流変更を追加して完全な血栓化を得た症例を報告して いる ${ }^{10)}$. なお, この症例の近位部 BA 閉塞は PCA と SCA の間で成されており，BA 穿通枝の血流は SCA に流れる 豊富な血流で維持されていた．また高橋らは部分血栓化巨 大中大脳動脈瘤に対する手術について 2 症例を元に考察 し，「穿通枝を盲端に残すと梗塞の危険性がある」，「動脈 瘤の血流遮断が成されなくとも，血流量が軽減すると瘤内 血栓化が起こり得る」という重要なコンセプトを示してい $る^{11)}$. Miyamoto らはこの新しいコンセプトに基づき治療 された部分血栓化巨大 BA top 動脈瘤の 6 症例について報 告している ${ }^{7)}$. 原則的に近位部 BA 閉塞(SCA 近位部閉塞) を併用しているが，BA からの分岐を離断することで動脈 瘤開口部を通過する灌流血流量を軽減し，その結果として water hammer effect を軽減し瘤内血栓化を達成してい
る，彼らは動脈瘤を完全に盲端化する場合を maximum flow reduction, 動脈瘤を通過する血流を残す形で terminal type flow reduction と分類している.

われわれの症例 1 では，BA の灌流血流量を軽減すべく 段階的に BA top の分岐を 4 本中 3 本離断した。つまり近 位部 BA 閉塞を行わずに順行性の血流を保ったまま flow reductionを行い, terminal typeを side wall typeに変 更した，と表現できる．BA top 動脈瘤の中にはPCA と $\mathrm{SCA}$ の間で BA 遮断が可能な症例もあり，その場合は血 流がSCA に流入してBA 穿通枝は盲端化しない. しかし， 症例 1 では近位部 BA を閉塞させる場合, SCA 近位部で の閉塞になるため BA 穿通枝が盲端化する。この近位部 $\mathrm{BA}$ 閉塞 (SCA 近位部閉塞) に伴う脳幹への穿通枝障害を 回避する方策として，順行性の血流を保ったまま灌流領域 の減少を計る戦略とした。 その後, 一時的には動脈瘤の縮 小化を認めたものの，再増大を示したため，動脈瘤内コイ ル塞栓術と VA-PICA 動脈瘤の治療も兼ねて片側のVA 閉 塞を行い, 供給血流量軽減も行った。これら灌流血流量の 軽減に, 供給血流量の軽減を追加することで最終的に動脈 瘤への血行力学的負荷が十分に軽減され, その結果, 病変 の存在する脳循環系が低灌流状態となり, 脳動脈瘤の増大 を抑制しえたと考える. 血栓化脳動脈瘤の瘤内コイル塞栓 術は再増大が多く，根治的ではない2)。しかし灌流血流量 軽減, 供給血流量軽減を併用した症例 1 のような状況では, 瘤内血栓化を効果的に促進する可能性もあるものと考元 る. 症例 2 は症例 1 と同様のコンセプトで, 動脈瘤に対す る血流負荷の軽減を目的に, 灌流領域を限定する戦略とし た．この治療コンセプトは瘤内血栓化促進には有効で，血 栓化とサイズの縮小が得られた。 また，M1 の穿通枝は遠 位部の anterior temporal branch に順行性の血流がある ため, 脳梗塞に陥らなかった。しかし， M1 遮断部の遠位 に入った穿通枝が脳梗塞に陥った，M2に high flow bypassを置いているが，この穿通枝は盲端に残される形 となり，前述の高橋の考察のとおり脳梗塞に陥った。この 微細な穿通枝の分岐情報を術前に把握することが今後の課 題と思われた.

症例 3 は動脈解離による pseudoaneurysm であり疾患 の entity としては症例 1 , 症例 2 と異なるが, 動脈瘤に対 する血流負荷を軽減して, かつ治療に伴う穿通枝梗塞を生 じさせない，という治療コンセプトは同様であった，動脈 瘤様隆起は pseudoaneurysm であることが強く示唆され, 瘤内コイル塞栓術のリスクは高かったが, framing coil が 安全に十分な形で形成できたため，無理のない範囲で瘤内 塞栓を施行した。同時に, 片側の VA を閉塞して flow reduction とした。しかし，このままでは動脈解離に対す 
る順行性の血流が残存しており，血流負荷をさらに軽減す る必要があると考え, flow outletを確保した形での血流 方向の変更を行った．同様の戦略は今田らによりすでに報 告されている ${ }^{4)}$. 彼らは動脈瘤様隆起が増大した BA trunk の解離性動脈瘤に対して二期的に両側の VA を閉塞 しており，結果として血流変更と PICAへの flow outに よる穿通枝梗塞の回避がなされている。一側の VA 閉塞 後約 3 力月間の観察をしていると, 片側が $1 \mathrm{~mm}$ 以下で あった p-com が両側とも $1 \mathrm{~mm}$ 以上になったため, BOT で脳虚血耐性を確認したのちに対側の VA も閉塞してい る。これは, 一側 VAの閉塞により側副血行路として p-com が育ったものと思われ, 待機的治療の有用性を示し たものである．形態が変化したが再破裂はしていない今田 らの症例とは異なり, われわれの症例 3 は再破裂していた ためなんらかの対応が必要であり, 脳血管攣縮期を過ぎた 時点ですみやかに治療を開始した，症例 3 では血流の向き を変更して解離性動脈瘤に順行性の負荷がかからないよう にしたが，吻合血管が受け持つ領域は全体としては広範囲 であったため, 術前のBOTは行わず high flow bypass を選択した． 経験的には片側の p-com が $1 \mathrm{~mm}$ 以上であ れば，追加する血管吻合は low flow bypass で十分であ ると考えている (personal communication). 後方循環の 親血管閉塞に対する BOT の評価は, 症状の観察・SEP • $\mathrm{ABR}$ ・脳血管撮影所見など複数の検査項目を組み合わせ るのが安全と思われるが, 明確な基準を示すことは困難で ある. 症例ごとに親血管閉塞後の血流を十分に勘案して, どのような血管吻合を併用するべきなのかを検討すること が重要である.

現在はデバイスの進歩に伴い, 頭蓋内主幹動脈に対する ステント留置も一般化してきている. 解離性脳動脈瘤に対 してステントアシスト，またはステント留置のみで治療し て良好な結果が得られたとする報告も多くみられ吕)14), 今 後の治療の方向性が示唆されている. 動脈解離部位の穿通 枝は，ステントストラットから血流が保たれるという実験 結果もあり ${ }^{5)}$, 動脈解離に対するステント留置に伴う脳梗 塞の危険はあまり高くないと想定される。 ただし, 周術期 に抗凝固療法が, 術後に抗血小板剤 2 剂以上の内服が必要 であり, 出血性合併症との利害については十分な検討が必 要である.

\section{結＼cjkstart語}

今回われわれが報告した 3 例で虜内血流の遮断が困難な 脳動脈瘤に対する治療法を一般化することは難しい. しか し，「動脈瘤に対する血流負荷を軽隇する」「治療に伴う合 併症, 特に穿通枝障害を生じさせない」という治療コンセ プトを元に，血管吻合技術や脳血管内治療を組み合わせる
ことで，疾患の自然史に介入し動脈瘤が治療直後に閉塞し なくとも患者予後の改善に貢献しうる「動脈瘤と共存す る」治療戦略を立てることは可能と考える.

\section{文献}

1) Chiaradio JC, Guzman L, Padilla L, et al: Intravascular graft stent treatment of a ruptured fusiform dissecting aneurysm of the intracranial vertebral artery: technical case report. Neurosurgery 50: 213-216, 2002

2) Ferns SP, van Rooij WJ, Sluzewski M, et al: Partially thrombosed intracranial aneurysms presenting with mass effect: long-term clinical and imaging follow-up after endovascular treatment. Am $J$ Neuroradiol 31: 1197-1205, 2010

3) Greenberg E, Katz JM, Janardhan V, et al: Treatment of a giant vertebrobasilar artery aneurysm using stent grafts. Case report. J Neurosurg 107: 165-168, 2007

4）今田裕尊, 井川房夫, 大林直彦, ほか：破裂脳底動脈解離 性動脈瘤に対して flow reverseにより治療し得た 1 例. 脳 神経外科 33: 587-592, 2005

5) Kallmes DF, Ding YH, Dai D, et al: A new endoluminal, flow-disrupting device for treatment of saccular aneurysms. Stroke 38: 2346-2352, 2007

6) Kellner CP, Haque RM, Meyers PM, et al: Complex basilar artery aneurysms treated using surgical basilar occlusion: a modern case series. Clinical article. J Neurosurg 115: 319-327, 2011

7) Miyamoto S, Funaki $T$, Iihara K, et al: Successful obliteration and shrinkage of giant partially thrombosed basilar artery aneurysms through a tailored flow reduction strategy with bypass surgery. J Neurosurg 114: 10281036, 2011

8) Roccatagliata L, Guédin P, Condette-Auliac S, et al: Partially thrombosed intracranial aneurysms: symptoms, evolution, and therapeutic management. Acta Neurochir (Wien) 152: 2133-2142, 2010

9) Steinberg GK, Drake CG, Peerless SJ: Deliberate basilar or vertebral artery occlusion in the treatment of intracranial aneurysms. Immediate results and long-term outcome in 201 patients. $J$ Neurosurg 79: 161-173, 1993

10) Takahashi JC, Murao K, Iihara K, et al: Successful "blind-alley" formation with bypass surgery for a partially thrombosed giant basilar artery tip aneurysm refractory to upper basilar artery obliteration. Case report. $J$ Neurosurg 106: 484-487, 2007

11）高橋 淳, 宮本 享: 解剖を中心とした脳神経手術手技. 部分血栓化巨大中大脳動脈瘤に対する手術. No Shinkei Geka 39: 129-139, 2011

12）氏家 弘, 比嘉 隆, 堀 智勝: 【椎骨脳底動脈 thrombosed aneurysmの病態と治療】Dolichoectatic basilar aneurysm の自然予後および現在の治療状況一アンケート調査 の分析. 脳卒中の外科 32: 338-345, 2004

13）氏家 弘, 上山博康, 比嘉 隆, ほか：【大型一巨大脳動脈 瘤の外科治療】後頭蓋窩血栓性巨大脳動脈瘤の外科治療. 脳卒中の外科 37: 149-155, 2009

14) Yoon WK, Kim YW, Kim SR, et al: Angiographic and clinical outcomes of stent-alone treatment for spontaneous vertebrobasilar dissecting aneurysm. Acta Neurochir (Wien) 152: 1477-1486, 2010 